\title{
Kecemasan Siswa Sekolah Menegah Atas dalam Menyelesaikan Masalah pada Materi Program Linier dalam Praktek Kelas Virtual
}

Ignes Febryliani, Khoerul Umam, Joko Soebagjoyo, Samsul Maarif

How to cite : Febryliani, I., Umam, K., Soebagjoyo, J., Maarif, S., 2021. Kecemasan Siswa Sekolah Menegah Atas dalam Menyelesaikan Masalah pada Materi Program Linier dalam Praktek Kelas Virtual. Kognitif: Jurnal Riset HOTS Pendidikan Matematika. 1(1). 34-52. https://doi.org/10.51574//ognitif.v1i1.12

To link to this article : https://doi.org/10.51574/kognitif.v1i1.12

Opened Access Article

11. Published Online on 1 Juni 2021

舟 Submit your paper to this journal 


\title{
Kecemasan Siswa Sekolah Menegah Atas dalam Menyelesaikan Masalah pada Materi Program Linier dalam Praktek Kelas Virtual
}

\author{
Ignes Febryliani ${ }^{1}$, Khoerul Umam ${ }^{1}$, Joko Soebagjoyo ${ }^{1}$, Samsul Maarif ${ }^{1}$ \\ ${ }^{1}$ Program Studi Pendidikan Matematika, Universitas Muhammadiya Prof. DR. HAMKA
}

\begin{tabular}{l} 
Article Info \\
\hline Article history: \\
Received Mar 14, 2021 \\
Accepted Apr 29, 2021 \\
Published Online Juni 1, 2021 \\
\hline
\end{tabular}

Keywords:

Kecemasan Matematis

Program Linear

Pemecahan Masalah

\begin{abstract}
Pembelajaran matematika secara virtual telah mengubah bagaimana siswa merespons situasi belajar dan tidak jarang meningkatkan kecemasan siswa. Tujuan dari penelitian ini mengungkapkan secara deskriptif bagaimana kecemasan yang terjadi pada siswa pada saat mempelajari program linear dalam pembelajaran matematika secara virtual. Metode penelitian ini menggunakan metode kuantitatif dengan menggunakan survey secara online agar dapat menjangkau seluruh subjek penelitian. Analisis data penelitian dideskripsikan secara deskriptif untuk mengilustrasikan kecemasan yang terjadi pada siswa pada kelas virtual. Hasil penelitian menunjukkan kecemasaan siswa pada saat mempelajari materi program linear meningkat pada aspek penilaian dimana kebayakan siswa meminta untuk diajarkan ulang materi yang sudah dipelajari. Kontribusi penelitian ini berdampak pada bagaimana belajar matematika yang efektif dan baik sehingga kecemasan yang terjadi dapat meningkatkan pemahaman matematis siswa
\end{abstract} All rights reserved.

\footnotetext{
Corresponding Author:

Khoerul Umam,

Pendidikan Matematika,

Universitas Muhammadiya Prof. DR. HAMKA

Email: khoerul.umam@uhamka.ac.id
}

\section{Pendahuluan}

Pendahuluan harus jelas dan ditulis deskriptif, Pendahuluan paling tidak memuat lima hal yaitu (1) Pentingnya penelitian yang dilakukan dengan mengulas isu yang bersifat internasional maupun nasional dan upayakan menampilkan isu yang bersumber jelas; (2) tanggapan peneliti terkait isu yang disajikan; (3) hasil temuan dari penelitian sebelumnya terkait dengan isu yang disampaikan, kemudian memunculkan gap penelitian yang dilakukan dengan penelitian-penelitian sebelumnya; (4) kebaruan atau celah penelitian yang dilakukan didukung dengan teori yang relevan primer; dan (5) fokus penelitian yang dilakukan. Bagian ini merupakan paragraf terakhir dari bagian pendahuluan. Peneliti bisa menulis tujuan atau 
rumusan masalah penelitian yang dilakukan dan ditulis deskriptif, tidak menggunakan bullet dan numbering.

Matematika merupakan mata pelajaran yang berkaitan dengan kehidupan sehari-hari maka perlunya siswa mengetahui konsep dasar matematika di sekolah (Indrawatiningsih, 2017; Vitasari et al., 2010). Namun beberapa siswa merasa takut ketika menghadapi matematika dan siswa merasa rendah dipelajaran matematika karena sulit dipahami (Șengül \& Dereli, 2010). Siswa yang kesulitan dalam memahami matematika karena matematika melibatkan banyak rumus dan perhitungan yang rumit serta kurangnya kemampuan untuk membangun pengetahuannya terhadap matematika (Georgewill, 1990). Ketika siswa mengalami kesulitan dalam memahami matematika, akan timbul rasa cemas yang disebabkan oleh mathematics anxiety atau kecemasan matematika (Wahid et al., 2014)

Kecemasan matematika akan muncul rasa kurang percaya diri dan takut saat siswa melakukan sesuatu yang berhubungan dengan angka atau persoalan matematika dalam kebiasaan umum maupun akademik (Richardson \& Suinn, 1972). Kecemasan matematika merupakan perasaan tegang, khawatir, takut yang dapat mempengaruhi kemampuan siswa terhadap matematika (Ashcraft, 2002). Siswa yang mengalami kecemasan akan merasa terhambat dalam berpikir akibat kuranngya pengetahuan matematika dan cenderung tidak menemukan solusi dan strategi tertentu sehingga menyebabkan menurunnya minat dan kepercayaan diri terhadap pembelajaran dan kemampuan matematika (Ashcraft, 2002; Kargar et al., 2010) Kecemasan siswa dalam belajar matematika merupakan hal yang perlu diperhatikan. Adanya kecemasan siswa disebabkan oleh beberapa faktor yang berdampak bagi siswa, yaitu faktor internal yang muncul dari kognitif dan diri siswa yang mempengaruhi kondisi fisik dan psikologis seperti cemas, takut, gugup dll. dan faktor eksternal yang muncul dari lingkungan seperti keluarga, guru, teman atau masyarakat (Aarnos \& Perkkilä, 2012). Menurut (Wahid et al., 2014) dalam penelitiannya faktor emosional dan faktor lingkungan paling tinggi dalam kecemasan matematika.

Tingkat kecemasan matematika yang tinggi dan kemampuan siswa yang masih rendah dalam memecahkan persoalan matematika dapat mempengaruhi prestasi siswa terhadap pembelajaran matematika (Hembree, 1990; Lee, 2009). Kecemasan sering terjadi dan dialami oleh siswa, dalam peneltian (Devine et al., 2012) mengungkapkan bahwa antara siswa laki-laki dan siswa perempuan, yang memiliki tingkat kecemasan lebih tinggi adalah siswa perempuan dan (Sorvo et al., 2017) mengatakan bahwa kecemasan matematika sudah ada pada anak-anak sejak kelas satu. Penyebab adanya rasa takut dan cemas yang dirasakan oleh siswa karena persepsi yang ada di lingkungan sekitarnya yang mempunyai pengalaman buruk di kelas matematika dan guru matematika sehingga siswa akan berpikir bahwa matematika merupakan mata pelajaran yang rumit, abstrak dan tidak menyenangkan serta merasa tidak mampu untuk menyelesaikan matematika (Aarnos \& Perkkilä, 2012). Maka dari itu pentingnya perhatian dan sikap keluarga yang faktor utama dalam meningkatkan atau menurunkan kecemasan matematika (Finlayson, 2014).

Kecemasan siswa dalam belajar matematika salah satunya pada materi Program Linier di Sekolah Menengah Atas. Program Linier merupakan salah satu materi matematika yang dipelajari siswa di sekolah yang berkaitan dengan kehidupan sehari-hari namun masih terdapat beberapa siswa kesulitan dalam memahaminya. Kesulitannya dikarenakan menggunakan sistem pertidaksamaan linier dan kemampuan untuk mengubah permasalahan sehari-hari kedalam bentuk model matematika serta membuat grafik yang merupakan prasyarat dalam mengerjakan program Linier (Bakhri et al., 2019). Dalam menyelesaikannya membutuhkan langkah-langkah yang panjang dan waktu yang lama (Bayu, 2015) sehingga menyebabkan adanya rasa kecemasan siswa dalam memahami dan menyelesaikan permasalahan pada materi Program Linier. 
Sejak adanya COVID-19 di dunia termasuk di Indonesia, Menteri Pendidikan dan Kebudayaan (MENDIKBUD) Indonesia membuat kebijakan kepada seluruh pelajar di Indonesia untuk melakukan pembelajaran di rumah. Adanya kebijakan tersebut untuk mencegah penularan COVID-19 agar pelajar tidak melakukan intensitas kontak fisik dengan orang lain. Akibat pandemi COVID-19 membuat pembelajaran tatap muka sebelumnya menjadi pembelajaran daring (online). Pembelajaran daring merupakan proses pembelajaran yang inovatif dan fleksibel yang berpusat pada siswa secara sinkron atau asinkron dengan menggunakan perangkan seperti laptop, hp dan membutuhkan akses internet (Bunyamin et al., 2020; Dhawan, 2020; Umam et al., 2019). Pembelajaran secara daring atau pembelajaran jarak jauh merupakan kegiatan belajar mengajar dimana pelajar melakukan pembelajaran di rumah dengan mengikuti kelas virtual. Terutama bagi siswa, melalui pembelajaran daring di kelas virtual akan ada kecemasan setiap siswa dalam proses belajar. Seperti pada materi program linier akan timbul kecemasan siswa, misalnya siswa akan cemas karena belum paham materi yang diajarkan gurunya atau ketika siswa harus menyelesaikan soal-soal program linier serta keterlambatan saat pengumpalan tugas. Penelitian ini bertujuan untuk mendeskripsikan kecemasan siswa dalam menyelesaikan masalah pada materi program linier dalam praktek kelas virtual agar mendapat hasil belajar yang memuaskan.

Berdasarkan penjelasan latar belakang yang telah diuraikan, maka terdapat permasalahan yang dapat teridentifikasi, yaitu:

1. Apakah terdapat kecemasan siswa menengah atas dalam menyelesaikan masalah pada materi program linier dalam praktek kelas virtual?

2. Faktor apakah yang mempengaruhi kecemasan siswa menengah atas dalam menyelesaikan masalah pada materi program linier dalam praktek kelas virtual?

\section{Kecemasan Matematika}

Kecemasan matematika atau mathematics anxiety serupa dengan "kecemasan angka" yang sering dianggap sebagai kecemasan dalam matematika (Kargar et al., 2010). Timbulnya kecemasan matematika karena aspek lingkungan, pribadi atau kognitif (Aarnos \& Perkkilä, 2012). Terdapat definisi mengenai kecemasan matematika, menurut (Richardson \& Suinn, 1972) kecemasan matematik akan muncul rasa kurang percaya diri dan takut saat seseorang melakukan sesuatu yang berhubungan dengan angka atau persoalan matematika dalam kebiasaan umum maupun akademik. Selain itu, (Ashcraft \& Faust, 1994) mengungkapkan bahwa rasa tertekan, cemas, ketakutan disertai masalah pada angka dalam menyelesaikan soal matematika. Sedangkan, (Ashcraft, 2002; Hembree, 1990) mengatakan kecemasan matematika didefinisikan sebagai pengalaman buruk yang mempengaruhi pikiran siswa terhadap matematika sehingga siswa kurang percaya diri dan menghindari pembelajaran matematika.

Berdasarkan definisi yang telah diuraikan, jadi kecemasan matematika merupakan suatu situasi yang menimbulkan perasaan cemas, gugup, ketakutan serta tidak percaya diri yang dirasakan oleh seseorang ketika berhadapan dengan matematika dan menyelesaikan persoalanpersoalan matematika.

Menurut Elliot (Saputra, 2014) menyatakan bahwa terdapat 3 jenis orang yang merasa cemas tehadap matematika yaitu pertama, the mathematics memorizer adalah seseorang yang menghafal matematika tapi mereka tidak menerapkan konsep matematika yang diperolehnya. Kedua, the mathematics avoider adalah seseorang yang menolak untuk belajar matematika. Ketiga, the self professed mathematics incompetent adalah seseorang yang merasa tidak paham pada mata pelajaran matematika. 
Siswa yang memiliki kecemasan matematika akan timbul gejala-gejala seperti yang dijelaskan menurut Broddy, yaitu:

1. Panik, siswa merasa menjadi lemas dimana siswa menghadapi masalah yang serius dan merasa sudah tidak sanggup menghadapi masalah terhadap pelajaran matematika.

2. Paranoia, dimana siswa menganggap semua orang mengetahui jawaban dari soal matematika kecuali diri dia sendiri. Merasan dirinya bodoh dan semua orang mengetahuinya.

3. Pasif, siswa tidak mecoba untuk melakukan apapun demi prestasinya seakan-akan kapasitas kemampuanya hanya sampai situ saja.

4. Kurang percaya diri, siswa merasa rendah diri atas kemampuannya dan lebih baik menghafalkan rumus dari pada memahami konsep matematika.

Timbulnya kecemasan yang dirasakan siswa, ada berbagai macam yang dialaminya. Menurut Freud (Saputra, 2014) ada tiga macam kecemasan yang terjadi pada seseorang:

1. Kecemasan Realistik

Merupakan perasaan takut ketika terjadi masalah dan tingkat kecemasanya sesuai dengan masalah yang terjadi dan dialaminya. Maksud dari kecemasan realistik adalah seseorang yang memiliki perasaan takut.

2. Kecemasan Moral

Merupakan ketika seseorang merasakan cemas namun ancaman bukan datang dari luar atau dari fisiknya tapi perasaan ego yang menghasut pikiran seseorang. Maksud dari kecemasan moral adalah seseorang yang memiliki perasaan malu.

3. Kecemasan Neurotik

Merupakan ketakutan yang disebabkan oleh rangsangan ide, seperti merasa lupa dengan gagasannya, kebingungan, tidak bisa mengendalikan emosi, perilaku, dan pikiraan. Maksud dari kecemasan neurotik adalah seseorang yang memiliki perasaan gugup.

Munculnya rasa cemas yang dirasakan siswa disebabkan karena beberapa faktor yang mempengaruhinya yaitu mempunyai latar belakang yang tidak menyenangkan, situasi kelas, bimbingan orang tua, kemampuan pemahaman yang tidak baik (Scarpello, 2007). Adapun, seperti yang dijelaskan oleh Trujillo \& Hadfiel (Peker, 2009) bahwa faktor kecemasan siswa yang berpengaruh dalam kesulitan belajar siswa adalah:

1. Faktor Internal atau psikolog yaitu ketakutan siswa terhadap kemampuan yang dimilikinya, berkurangnya minat dan motivasi siswa akibat kurang percaya diri, misalnya siswa yang memiliki masa lalu yang tidak mengasyikkan terhadap matematika akan merasa pesimis, cemas, takut.

2. Faktor Eksternal atau lingkungan yaitu ketegangan dalam belajar matematika yang disebabkan oleh metode, model, cara mengajar guru serta tekanan kelurga yang membuat siswa harus pintar dalam belajar matematika.

3. Faktro Intelektual bersifat kognitif, yaitu fokus pada bakat dan tingkat intelektual siswa.

Dalam kecemasan matematika juga ada tingkatan kecemasan siswa yang patut diketahui agar dapat mengurangi atau mengatasi kecemasan pada diri siswa. Menurut Peplau (Sugiatno et al., 2017) terdapat 4 tingkat kecemasan yang dialami setiap orang yaitu: 
1. Kecemasan ringan, yaitu terkait ketegangan yang dialami setiap hari, seseorang masih bisa mengendalikannya dan dapat memotivasi diri untuk semangat belajar dan mampu mengatasi masalah secara efektif dan kreatif.

2. Kecemasan sedang yaitu seseorang yang hanya terfokus pada sesuatu yang telah menganggu pikirannya, sulit berpikir untuk mencari solusi namun masih melakukan sesuatu arahan dari orang lain.

3. Kecemasan berat, yaitu seseorang mempunyai pemikiran yang sempit atau sulit berpikir untuk mencari solusi dan lainnya. Sangat membutuhkan arahan atau perintah agar lebih fokus dan untuk mengurangi kecemasan

4. Panik, yaitu seseorang tidak dapat mengontrol diri dan tidak fokus sehingga tidak mampu melakukan apapun meskipun sudah diberi arahan. Merasa sangat gugup, tidak dapat berpikir rasional dan sulit berinteraksi dengan orang lain terkadang timbul diorganisasi kepribadian.

Adapun cara yang dapat digunakan untk mengurangi kecemasan matematika menurut Woodard yaitu:

1. Menciptakan suasana pembelajaran matematika yang menyenangkan, tidak menakutkan dan santai.

2. Membuat kelompok kecil sebagai tempat untuk berdiskusi agar bisa saling membantu dan memhami masalah.

3. Tidak menjelaskan materi dengan terburu-buru agar siswa lebih mudah memahaminya.

4. Mengadakan waktu tambahan agar tidak ada siswa yang ketinggalan secara akademis.

\section{Pembelajaran Matematika Pada Kelas Virtual}

Matematika merupakan pelajaran yang wajib dipelajari di sekolah dengan biasa dilakukan proses pembelajarannya secara tatap muka. Saat masa pandemi COVID-19 pembelajaran matematika berubah menjadi pembelajaran daring melalui kelas virtual. Dalam hal ini pelaksaaan kelas virtual sebagai sarana dalam proses pembelajaran antara guru dengan siswa yang menggunakan jaringan internet sebagai pengganti dari belajar tatap muka disekolah untuk mencapai tujuan belajar dan meningkatkan hasil belajar siswa pada masa pandemi COVID-19.

Adapun terdapat beberapa definisi mengenai kelas virtual, menurut (Dhawan, 2020) menjelaskan bahwa proses pembelajaran yang inovatif dan fleksibel yang berpusat pada siswa secara sinkron atau asinkron dengan menggunakan perangkat seperi laptop, hp dan membutuhkan akses internet. Sedangkat menurut (Moore et al., 2011) yaitu pembelajaran daring yang menggunakan media pembelajaran seperti aplikasi, program, dan situs web sehingga siswa masih bisa belajar secara online. Selain itu, (Govindasamy, 2001) mengatakan bahwa proses pembelajaran yang merupakan cara belajar dan mengajar yang berbeda dari sebelumnya, dengan melaui semua media elektronik termasuk internet, siaran, audio atau video.

Pembelajaran yang diberlakukan secara online merupakan suatu sistem layanan kelas virtual yang dapat diakses dengan mudah, tidak perlu mengeluarkan biaya yang banyak, siswa dapat belajar lebih luas dengan fasilitasi yang telah disediakan. Dalam proses belajar, siswa hanya belajar melalui platform yang telah disediakan oleh gurunya dan tugas-tugas nya dapat dikirim melalui platform tersebut yang mana pembelajaran lebih mudah, efisien dan hemat 
waktu (Govindasamy, 2001; Ikram et al., 2021). Menurut Dhawan (2020), pembelajaran daring sangat fleksibel karena siswa dapat menjadwalkan dan merencanakan waktu dengan sendirinya untuk menyelesaikan pembelajaran secara online, siswa juga dapat belajar kapan pun dan dimana pun. Adanya pembelajaran daring, belajar mengajar berpusat pada siswa sehingga siswa mempunyai tanggung jawab atas pemahamannya terhadap materi dan mengatur aspek kognitif dan konstekstual dalam proses belajar, yang membuat siswa harus melakukan pembelajarannya secara mandiri dan kurang berinteraksi dengan siswa lainnya (Moore et al., 2011; Nabilah et al., 2021).

Dalam pembelajaran daring terdapat jenis pembelajaran yagn biasa dilakukan yaitu pembelajaran sinkron dan asinkron, menurut Dhawan (2020) perbedaan pembelajaran sinkron dan asinkron sebagai baerikut:

1. Pembelajaran Sinkron

Pembelajaran sinkron merupakan pembelajaran secara real time, yaitu pembelajaran lebih terstruktur dimana siswa dapat belajar secara langsung dan adanya interaksi antara siswa dan guru, pembelajaran yang dilakukan pada waktu yang bersamaan dengan menggunakan media langsung atau aplikasi seperti video sehingga dapat melakukan tanya jawab serta diskusi dan bebas berpendapat secara langsung juga.

2. Pembelajaran Asinkronus

Pembelajaran asinkron merupakan pembelajarannya kurang terstruktur, proses pembelajaran yang dilakukan tidak secara langsung. Sistem pembelajarannya dengan memberikan bahan pembelajaran melalui platform yang telah ditentukan. Siswa mempunyai waktu yang lebih fleksibilitas untuk menentukan waktu belajarnya sendiri, maka dari itu pembelajaran asinkron sering digunakan. Namun, dalam pembelajaran asinkron membuat kurangnya interakasi sesama siswa sehingga jika siswa tidak memahami materi yang diajarkan gurunya, siswa bisa mengalami kurangnya minat dan semangat belajar.

Agar siswa mencapai tujuan pembelajaran dalam pembelajaran darng, maka pentingnya siswa mempunyai karakteristik dan keterampilan menurut (Dabbagh, 2007) yang dianggap penting, sebagai berikut:

1. Mempunyai konsep diri mengenai akademik.

Perubahan proses belajar yang berbeda dari sebelumnya, siswa harus mempunyai konsep diri untuk mencapai tujuan pembelajaran.

2. Mengerti segala sesuatu yang berkaitan dengan teknologi.

Pembelajaran yang dilakukan menggunakan web, aplikasi dll sehingga siswa harus mengerti dan mahir dalam komputer apapun yang berkaitan dengan teknologi.

3. Mempunyai interpesonal dan komunikasi

Siswa harus mempunyai interpersonal dan komunikasi yang baik agar dapat berinteraksi dengan yang lainnya dalam pembelajaran daring.

4. Memahami dan menghargai dalam pembelajaran kolaboratif

Siswa bebas berpendapat saat melakukan pembelajaran berlangsung, sehingga siswa harus saling memahami dan menghargai pendapat siswa lainnya.

5. Dapat mengontrol diri saat pembelajaran berlangsung.

Siswa harus mampu mengontrol diri agar dapat memahami dan mengerti setiap materi.

6. Mempunyai keterampilan belajar mandiri. 
Kemampuan belajar mandiri sangat diperlukan, karena siswa harus memiliki perilaku diri seperti displin diri, insiatif diri dan memanajemen diri dalam pembelajaran online.

7. Membuktikan untuk dapat berafiliasi gar memberikan kepercayaan kepada siswa lainnya saat melakukan pengelompokan, agar kelompok tersebut menjadi kelompok yang berhasil.

Beberapa ciri-ciri siswa dalam belajar daring menurut (Dabbagh, 2007) yaitu giat belajar dimana siswa harus mempunyai niat dan keinginan yang tinggi dalam etika belajar, pemahaman materi dan mencari pengetahuan-pengetahuan secara mandiri. Memiliki literasi terhadap teknologi juga diperlukan agar siswa punya banyak pemahaman dan cara pemakaian yang berkaitan dengan teknologi. Siswa juga harus memiliki kemampuan berkomunikasi interpersonal dalam dirinya untuk berinteraksi dan hubungann sesama siswa. Perlu adanya kolaborasi sehingga siswa mampu bekerja sama dengan siswa lainnya dan juga sistem yang mendukung pembelajaran daring. Selain itu, keterampilan untuk belajar mandiri juga dipelukan agar siswa dapat mencari, menemukan dan meringkas dalam belajar mandiri.

Dalam masa pandemi seperti ini, menurut Dhawan (2020) pembelajaran daring cukup mudah diakses sehingga proses pembelajaran dapat tetap berjalan karena sebagai berikut:

1. Konferensi video dapat dilakukan antara 40-50 siswa

2. Siswa masih dapat berdiskusi dengan siswa lainnya agar proses pembelajaran tetap aktif juga.

3. Koneksi yang baik akan mudah mengaksesnya.

4. Kelas virtual dapat diakses lewat ponsel, tidak hanya lewat laptop.

5. Memungkinan belajar hanya dengan menonton video pembelajaran yang telah direkam oleh guru.

6. Umpan balik dari siswa cukup baik dan tugas-tugas yang diberikan mudah untuk diakses.

Adapun masalah kesulitan dalam kemampuan diri siswa ketika pembelajaran matematika di kelas virtual menurut Dhawan (2020) yaitu:

1. Kurangnya inisiatif siswa untuk belajar mandiri, siswa masih menunggu arahan dari gurunya.

2. Belum terbiasa dalam pembelajaran daring, siswa hanya mempelajari materi yang diberikan gurunya bukan yang mereka butuhkan.

3. Dalam tujuan belajar, siswa hanya memikirkan nilai bukan hasil dan kemampuan yang didapat untuk lebih ditingkatkan.

4. Beberapa siswa belum bisa mempelajari, mengatur dan mengontrol pembelajaran daring, terlihat masih seperti belajar seperlunya saja.

5. Kurangnya evaluasi diri sehingga siswa cepata putus asa saat mengalami kesulitan dan kemampuan dalam mengerjakan matematika.

\section{Kecemasan Siswa Pada Materi Program Linier Dalam Kelas Virtual}

Pada pembelajaran matematika banyak sekali materi-materi yang dipelajari oleh siswa di sekolah, salah satunya yaitu materi program linier. Program linier merupakan materi pelajaran yang berkaitan dengan kehidupan sehari-hari, dengan menggunakan sistem pertidaksamaan linier dua variabel, bentuk soal program linier biasanya terdapat lebih dari satu 
pertidaksamaaan. Dengan cara penyelesaiannya, sistem pertidaksamaan varibel yang diubah ke dalam bentuk model matematika lalu penyelesaiannya dengan metode eliminasi dan subsitusi, kemudian membuat grafik.

Siswa yang merasa sulit ketika menyelesaikan masalah pada materi program linier, kesulitan yang terjadi pada siswa saat menyelesaikan soal yang menggunakan sistem pertidaksamaan linier yang kemudian diubah kedalam model matematika yang merupakan prasayarat dalam menyelesaikan soal program linier (Bakhri et al., 2019). Ketika soal sudah diubah menjadi model matematika, langkah selanjutnya yaitu menggambar grafik dari setiap sistem pertidaksamaan variabel sesuai model matematika yang telah dibuat. Sehingga dalam menyelesaikan soal program linier membutuhkan langkah-langkah yang cukup panjang dan membutuhkan waktu pengerjaan yang cukup lama (Bayu, 2015).

Matematika merupakan pelajaran yang sulit dan tidak disenangi oleh siswa, salah satunya pada materi program linier. Siswa yang mengalami kesulitan menyebabkan timbulnya kecemasan dalam diri siswa. Kecemasan siswa dapat terjadi ketika siswa merasa dirinya tidak mampu mengatasi masalah yang sedang terjadi (Saputra, 2014). Kecemasan terhadap matematika sering dirasakan oleh siswa. Kecemasan yang tinggi dapat mempengaruhi buruk pada diri siswa terhadap matematika. Kecemasan yang dirasakan yang muncul terhadap matematika memiliki gejala seperti ketakutan, hilangnya minat belajar, tidak bisa berkonsentrasi, merasa kebingunan dan sulit untuk bersabar serta mengalami rasa tegang (Vitasari et al., 2010). Kecemaasan siswa pada materi prorgam linier, merasa bahwa ia tidak mampu menyelesaikan permasalahan dari soal program linier. Ketika siswa tidak bisa menyelesaikan permasalahan program linier, maka pemahaman dan kinerja siswa belum dikuasai oleh siswa (Kosiret et al., 2021; Nakhanu \& Musasia, 2015).

Ketika pembelajaran tatap muka berubah menjadi pembelajaran daring pada kelas virtual akibat covid-19, hal tersebut akan muncul kecemasan dalam diri siswa mengenai mata pelajaran program linier di kelas virtual karena persiapan diri dan persiapan belajar yang kurang memadai seperti waktu, tepat dan teknologi yang siswa miliki. koneksi dan kouta internet, keterlambatan mengumpulkan tugas. Adapun dengan keterbatasan waktu seperti siswa lupa atau telat mengumpulkannya karena keterbatasan waktu, jaringan yang sedang buruk menyebabkan siswa tidak bisa mengikuti pembelajaran atau ada perasaan panik saat ingin mengumpulkan tugas. Guru juga mempunyai waktu yang singkat, sehingga terdapat siswa yang kurang paham dari materi yang diajarkan gurunya.(Saputra, 2014)

Selain itu, siswa yang kurang interaksi atau kurang adanya diskusi secara langsung tatap muka antara siswa dengan guru dan siswa dengan siswa lainnya akan merasa kebingungan terutama jika tidak mengerti materi. Dalam kelas virtual guru menjelaskan materi tersebut melalui aplikasi pembelajaran atau video pembelajaran, Siswa yang tidak mengerti akan kebingungan bagaimana cara mengaplikasikan teknologi yang digunakan saat proses belajar (Dabbagh, 2007).

Adapun ringkasan dari kecemasan-kecemasan siswa yang akan dialami ketika kesulitan siswa saat pembelajaran daring, yaitu:

1. Kendala pada jaringan

2. Kurangnya interaksi

3. Keterbatasan waktu guru

4. Keterbatasan waktu siswa

5. Kurang pemahaman terhadap tekonologi

Menurut Nakhanu \& Musasia (2015) Metode pengajaran guru yang dilakukan juga perlu diperhatikan, guru yang monoton akan membuat siswa merasa bosan dan mengakibatkan siswa mengerti apa yang diajarkan oleh gurunya. Sehingga agar materinya lebih mudah dipahami, guru perlu mendorong siswa agar siswa semangat dan meningkatkan motivasinya 
dalam belajar program linier (Bayu, 2015). Sebab program linier merupakan mata pelajaran yang perlu dipelajari dan dipahami karena berkaitan dengan kehidupan sehari-hari dimana pelajaran tersebut sangat bermanfaat sampai kapan pun sering diterapkan dalam kehidupan terutama dalam bidang ekonomi, indsutri, kedokteran (Bayu, 2015). Program linier bisa bermanfaat untuk menghitung maksimum dan minimum atau kerugian dari sumber daya yang terbatas dalam kehidupan sehari-hari, dalam sebuah industri dan perusahaan dapat digunakan untuk mencari solusi untuk perhitungan suatu produksi (Nakhanu \& Musasia, 2015).

Menurut Denhere (Bakhri et al., 2019) dalam mengatasai kecemasan siswa terhadap matematika pada mata pembelajaran program linier dapat dilakukan dengan melakaukan penerapan pembelajaran kotekstual ke dalam kehidupan nyata, peneranpannya dengan cara siswa harus saling bekerja sama untuk meningkatkan pemahaman konsep siswa mengenai pembelajaran kontekstual dan konstruktivisme dan secara inkuiri dan kemudian pembelajaran tersebut dilakukan harus berkaitan dengan situasi kehidupan sehari-hari.

Menurut Pradeep (Bakhri et al., 2019) terdapat tahapan kecemasan matematika yaitu 1) Siswa yang mempunyai pengalaman yang buruk akan mempunyai perasaan yang buruk terhadap matematika, 2) Siswa menghindari dan tidak tertarik terhadap matematika, 3) siswa memiliki persiapaan yang kurang untuk belajar matematika, 4) kinerja siswa terhadap matematika kurang maksimal atau tidak mampu menyelesaikan persoalan matematika. Maka dari itu, pembelajaran daring dalam keberhasilan model pembelajaran atau media pembelajaran tergantung pada karakteristik siswa terutama pada mata pelajaran matematika. Siswa yang merasa cemas, kurang efektif dalam memahami materi dan merasa tidak berhasil dalam mencapai tujuan pembelajaran saat mengikuti kelas virtual (Hasan \& Bao, 2020). Hal ini dikarenakan faktor lingkungan belajar dan karakteristik siswa, oleh karena itu dalam pembelajaran daring dibutuhkan peran pendidik dan orang tua.

\section{Kerangka Berpikir}

Kecemasan adalah perasaan yang dialami seseorang ketika terjadi suatu masalah. Dalam pembelajaran matematika terdapat kecemasan matematika yang merupakan suatu situasi yang menimbulkan perasaan cemas, gugup, ketakutan serta tidak percaya diri yang dirasakan oleh seseorang ketika berhadapan dengan matematika dan menyelesaikan persoalan-persoalan matematika. Siswa yang merasakan adanya kecemasan dalam pembelajaran matematika akan mudah menyerah dan menyebabkan prestasi siswa menjadi rendah.

Kecemasan siswa terhadap matematika salah satunya pada materi program linier dimana siswa kesulitan dalam memahami dan menyelesaikan permasalahan terhadap materi program linier karena menggunakan pertidaksamaan yang diubah kedalam bentuk model matematika serta membuat grafik. Terutama pada pembelajaran tatap muka sebelumnya yang berubah menjadi pembelajaran daring dalam kelas virtual akibat COVID-19 akan ada kecemasan siswa yang berbeda-beda ketika belajar program linier dalam kelas virtual. Sehingga diperlukannya untuk mengetahui kecemasan siswa agar dapat mengurangi rasa kecemasan dan siswa dapat meningkatkan kemampuannya dalam menyelesaikan persoalan program linier. Penelitian ini dilakukan bertujuan untuk mengetahui kecemasan siswa sekolah menengah atas dalam menyelesaikan masalah pada materi program linier dalam praktek kelas virtual.

\section{Metode}

Desain penelitian dalam penelitian ini, metode penelitian yang digunakan yaitu metode survey dengan pendekatan kuantitatif. Menurut Sugiyono (2018) dalam metode survey, peneliti memberikan pertanyaan atau pernyataan kepada semua partispan atau responden mengenai 
pendapat, keyakinan atau karaktersitik setiap objek mengenai kecemasan siswa sekolah menengah atas dalam menyelesaikan masalah pada materi program linier dalam praktek kelas virtual. Tujuan dalam penelitian ini adalah untuk mengetahui tingkat kecemasan siswa sekolah menengah atas dalam menyelesaikan masalah pada materi program linier dalam praktek kelas virtual dan faktor apakah yang mempengaruhi siswa sekolah menengah atas dalam menyelesaikan masalah pada materi program liner dalam praktek kelas virtual.

\section{Partisipan}

Sampel pada penelitian ini diambil sebanyak 200 siswa kelas XI Sekolah Menengah Atas di daerah Jakarta, Bogor, Depok, Tangerang dan Bekasi yang sedang mengalami pembelajaran secara daring. Dalam mengisi kuesioner, siswa diminta untuk mengisi beberapa pertanyaan dasar atau demografi siswa yaitu jenis kelamin siswa, wilayah sekolah, durasi belajar, penggunaan media pembelajaran, platform yang digunakan selama pembelajaran daring dan kegiatan lain selain belajar online. Siswa yang telah mengisi demografi siswa melanjutkan pengisian kuesioner mengenai kecemasan siswa dalam menyelesaikan masalah pada materi program linier yang dibagi menjadi 3 kategori yaitu kategori emosi, kategori penilaian dan katogeri lingkunngan.

\begin{tabular}{|c|c|c|}
\hline \multirow{2}{*}{ Demografi } & \multicolumn{2}{|c|}{ Tabel 1. Demografi Siswa } \\
\hline & & $\mathbf{N}$ \\
\hline \multirow[t]{2}{*}{ Jenis Kelamin } & [1]Perempuan & 153 \\
\hline & [2] Laki-laki & 47 \\
\hline \multirow[t]{5}{*}{ Wilayah } & 1. Jakarta & 38 \\
\hline & 2. Bogor & 104 \\
\hline & 3. Depok & 7 \\
\hline & 4. Tangerang & 11 \\
\hline & 5. Bekasi & 40 \\
\hline \multirow[t]{3}{*}{ Durasi Belajar } & 1. Kurang dari 5 jam & 174 \\
\hline & 2. $10-15 \mathrm{jam}$ & 21 \\
\hline & 3. Lebih dari 15 jam & 5 \\
\hline \multirow{4}{*}{$\begin{array}{l}\text { Penggunaan Media } \\
\text { Pembelajaran }\end{array}$} & 1. Handhone & 187 \\
\hline & 2. Laptop & 78 \\
\hline & 3. Table & 3 \\
\hline & 4. Semuanya. & 8 \\
\hline \multirow{6}{*}{$\begin{array}{l}\text { Penggunakan Media } \\
\text { Pembelajaran }\end{array}$} & 1. Google Classroom & 181 \\
\hline & 2. Whatsapss & 80 \\
\hline & 3. Schoology & 7 \\
\hline & 4. Webiste dari sekolah & 15 \\
\hline & $\begin{array}{l}\text { 5. Website di luar } \\
\text { sekolah }\end{array}$ & 12 \\
\hline & 6. Email & 18 \\
\hline \multirow{5}{*}{$\begin{array}{l}\text { Kegiatan selain belajar } \\
\text { online selama pandemi }\end{array}$} & 1. Bermain & 56 \\
\hline & 2. Belajar & 83 \\
\hline & 3. Main Game & 36 \\
\hline & 4. Nonton TV/youtube & 107 \\
\hline & 5. Media Social & 147 \\
\hline
\end{tabular}




\section{Instrumen}

Dalam penelitian ini, instrumen yang digunakan berupa kuesioner untuk mengumpulkan data melalui google form. Kuesioner berisi 30 item pernyataan yang mengukur tingkat kecemasan siswa sekolah menengah atas pada materi program linier berdasarkan faktor emosi, penilaian dan lingkungan. Pernyataan kuesioner berasal dari instrumen (Wahid et al., 2014) dan dimodifikasi sesuai dengan keperluan penelitian.

Item pernyataan dari faktor emosi dan penilaian menggunakan lima poin skala likert yaitu "Sangat mirip seperti saya", "seperti saya", "agak seperti saya", "tidak seperti saya", dan "sangat tidak seperti saya" dengan jawaban tertinggi 5 yaitu "sangat mirip seperti saya" dan jawaban terendah 1 yaitu "sangat tidak seperti saya". Sedangkan untuk item pernyataan dari faktor lingkungan menggunakan 5 point skala likert yaitu "tidak pernah", "jarang", "kadangkadang", "sering" dan "sangat sering" dengan jawaban tertinggi 5 yaitu "sangat sering" dan jawaban terendah 1 yaitu "tidak pernah"

\section{Teknik Pengumpulan Data}

Teknik pengumpulan data dalam penelitian ini dilakukan secara daring melalui google. Adapun langkah-langkah dalam mengumpulkan data yang digunakan yaitu:

1. Peneliti memodifikasi instrument kecemasan siswa dari instrumen (Wahid et al., 2014) dan menyusun instrument digoogle form

2. Peneliti menentuntukan sampel kelas XI SMA di daerah Jabodetabek dengan menggunakan teknik purposive sampling

3. Peneliti memberikan kuesioner kepada subjek melalui google form

4. Subjek mengisi semua item pernyataan sesuai dengan keadaan yang dirasakan selama pembelajaran daring

\section{Data Analisis}

Statistik deskriptif digunakan untuk mengetahui tingkat kecemasan siswa sekolah menengah atas dalam menyelesaikan masalah pada materi program linier dalam praktek kelas virtual. Kuesioner dibagikan dan disebaluaskan melalui google from kepada siswa kelas XI SMA di daerah Jakarta, Bogor, Depok, Tangerang dan Bekasi yang sedang mengalami pembelajaran daring. Partisipan yang dibutuhkan yaitu 200 responden agar memenuhi target atau pencapaian dalam penelitian ini. Partisipan pada penelitian ini bersifat sukarela dan tidak beresiko atau manfaaat yang teridentifikan pada partipan.

\section{Diskusi dan Hasil Penelitian}

\section{Kecemasan Kategori Emosi}

Tabel 2. Kategori: Emosi

\begin{tabular}{lccc}
\multicolumn{1}{c}{ Pernyataan } & Mean & SD & Rank \\
\hline $\begin{array}{l}\text { Saya merasa seperti tidak bisa mengontrol nilai matematika } \\
\text { saya pada materi program linier. }\end{array}$ & 3.12 & 1.047 & 1 \\
\hline $\begin{array}{l}\text { Saya merasa jantung saya berdebar kencang saat mengerjakan } \\
\text { atau memikirkan materi program linier. }\end{array}$ & 2.46 & 1.270 & 4 \\
\hline $\begin{array}{l}\text { Saya menjadi kesal saat mengerjakan atau memikirkan materi } \\
\text { program linier. }\end{array}$ & 2.88 & 1.777 & 2 \\
$\begin{array}{l}\text { Tangan saya berkeringat saat mengerjakan atau memikirkan } \\
\text { materi program linier. }\end{array}$ & 2.13 & 1.180 & 7 \\
\hline $\begin{array}{l}\text { Saya merasa gugup saat mengerjakan atau memikirkan materi } \\
\text { program linier. }\end{array}$ & 2.67 & 1.275 & 3 \\
\hline
\end{tabular}




\begin{tabular}{lccc}
\hline $\begin{array}{l}\text { Perut saya sakit ketika mengerjakan atau memikirkan materi } \\
\text { program linier. }\end{array}$ & 1.76 & 1.005 & 10 \\
\hline $\begin{array}{l}\text { Saya merasa tegang dan kaku saat mengerjakan atau } \\
\text { memikirkan materi program linier. }\end{array}$ & 2.32 & 1.188 & 6 \\
\hline $\begin{array}{l}\text { Saya sulit tidur setelah mengerjakan materi program linier } \\
\text { atau ketika besok adapelajaran atau ujian materi program } \\
\text { linier. }\end{array}$ & 1.99 & 1.146 & 8 \\
\hline $\begin{array}{l}\text { Saya sering merasa ingin buang air kecil saat berada di kelas } \\
\text { materi program linier, mengerjakan materi program linier atau } \\
\text { ujian materi program linier. }\end{array}$ & 1.85 & 1.024 & 9 \\
\hline $\begin{array}{l}\text { Saya merasa sakit kepala dan leher yang kaku saat } \\
\text { mengerjakan atau memikirkan materi program linier. }\end{array}$ & 2.39 & 1.290 & 5 \\
\hline
\end{tabular}

Tabel 2, memberikan ringkasan kuesioner siswa. Secara umum siswa merasa tidak dapat mengontrol nilai matematikanya pada materi program linier $(\mathrm{M}=3.12, \mathrm{SD}=1.047)$. Hal ini sesuai dengan (Devine et al., 2012) bahwa kecemasan siswa yang muncul dalam diri siswa dapat memberikan dampak negatif terutama sikap tidak mampu menyelesaikan tugas matematika atau menghindari kelas matematika. Kurangnya minat belajar dan motivasi belajar siswa akan merasa kesulitan ketika menyelesaikan persoalan program linier yang menggunakan sistem pertidaksamaan linier dan grafik sehingga siswa akan mendapatkan nilai yang rendah. Hal ini sependapat dengan (Radišić et al., 2015) bahwa pengaruh kecemasan matematika dan kurangnya motivasi siswa dapat menghambat prestasi belajar siswa yang sangat rendah. Sehingga siswa harus mempunyai minat dan motivasi dalam belajar untuk menguasai materi program linier agar terhindar dari kegagalan. Ketika siswa yang merasa dirinya tidak mampu menguasai materi program linier akan merasa kesulitan dalam menyelesaikan persoalan program linier dan menimbulkan perasaan negatif seperti kesal akibat kemampuannya yang rendah, sesuai dengan pernyataan dari "siswa kesal saat mengerjakan atau memikirkan materi program linier" $(\mathrm{M}=2.88, \mathrm{SD}=1,777)$. Hal ini sependapat dengan (Aarnos \& Perkkilä, 2012) bahwa penyebab adanya kecemasan dalam matematika akan melibatkan emosi yang negative. Siswa yang mengalami hal tersebut dikarenakan adanya kecemasan yang muncul saat kesulitan dan tidak memahami bagaimana cara menyelesaikan permasalahan persoalan program linier. Perasaan emosi yang dialami siswa dapat mempengaruhi psikologis dan fisik siswa terhada matematika. Siswa yang merasa sangat cemas akan menimbulkan ciri-ciri fisik seperti sesuai dengan pernyataaan "Saya merasa gugup saat mengerjakan atau memikirkan materi program linier" $(\mathrm{M}=2.67, \mathrm{SD}=1.275)$ dan "Saya merasa jantung saya berdebar kencang saat mengerjakan atau memikirkan materi program linier" $(\mathrm{M}=2.46, \mathrm{SD}=1.270)$

\section{Faktor Emosi}

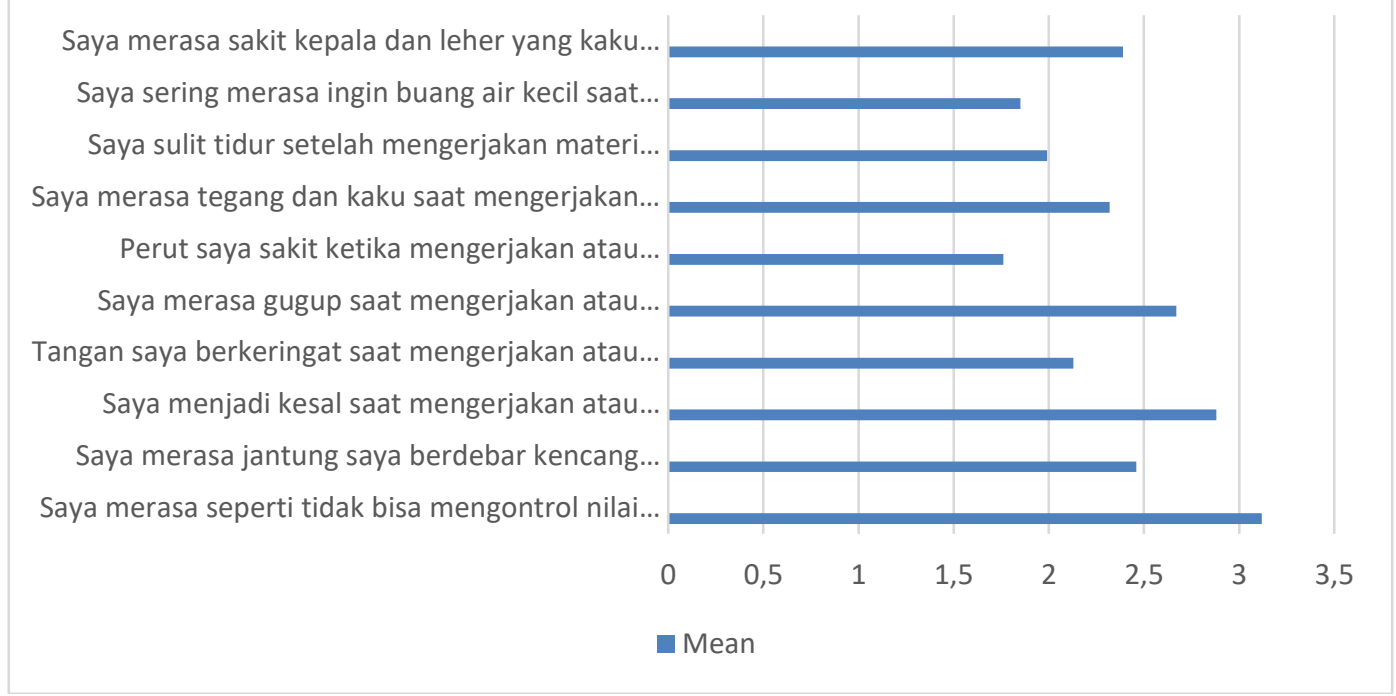


Pernyataan rata-rata kecemasan paling banyak pada siswa yaitu "Saya merasa seperti tidak bisa mengontrol nilai matematika saya pada materi program linier." dengan nilai $\mathrm{M}=$ $3.12, \mathrm{SD}=1.047$. Sedangkan pernyataan rata-rata kecemasan paling sedikit pada siswa yaitu "Perut saya sakit ketika mengerjakan atau memikirkan materi program linier." $(M=1,76, \mathrm{SD}$ $=1.005)$.

\section{Kecemasan kategori Penilaian}

Tabel 3. Kategori: Penilaian

\begin{tabular}{lccc}
\hline \multicolumn{1}{c}{ Pernyataan } & Mean & SD & Rank \\
\hline $\begin{array}{l}\text { Saya cenderung tidak dapat mengerjakan ujian materi program } \\
\text { linier dengan baik. }\end{array}$ & 3.12 & 1.066 & 7 \\
\hline $\begin{array}{l}\text { Saya merasa saya perlu banyak persiapan lebih untuk ujian } \\
\text { materi program linier atau mata pelajaran lainnya. }\end{array}$ & 4.21 & .991 & 1 \\
\hline $\begin{array}{l}\text { Ujian materi program linier membuat saya stress dari pada mata } \\
\text { pelajaran lainnya. }\end{array}$ & 2.77 & 1.140 & 10 \\
\hline $\begin{array}{l}\text { Ketika belajar untuk ujian materi program linier, terdapat } \\
\text { kecemasan dalam diri saya. }\end{array}$ & 2.93 & 1.229 & 9 \\
\hline $\begin{array}{l}\text { Saya merasa bahwa saya dapat memahami materi program linier } \\
\text { di kelas tapi tidak dapat mengerjakannya saat ujian. }\end{array}$ & 3.47 & 1.158 & 3 \\
\hline $\begin{array}{l}\text { Saya sulit berkonsentrasi selama ujian materi program linier. } \\
\text { Saya tidak percaya diri saat mengerjakan ujian materi program } \\
\text { linier walaupun saya sudah banyak belajar. }\end{array}$ & 3.07 & 1.144 & 8 \\
\hline $\begin{array}{l}\text { Saya merasa bahwa saya tidak percaya diri dengan ide atau } \\
\text { metode saya dalam menyelesaikannya selama ujian materi } \\
\text { program linier. }\end{array}$ & 3.19 & 1.159 & 4 \\
\hline $\begin{array}{l}\text { Saya merasa bahwa ujian dalam mata pelajaran apapun adalah } \\
\text { cerminan dari nilai kepribadian saya. }\end{array}$ & 3.21 & 1.266 & 6 \\
\hline $\begin{array}{l}\text { Selama ujian materi program linier, saya membandingkan } \\
\text { perkembangan diri saya dengan orang di sekitar saya. }\end{array}$ & 3.54 & 1.192 & 2 \\
\hline
\end{tabular}

Tabel 3, memberikan ringkasan hasil kusioner siswa pada faktor penilaian. Secara umum, siswa setuju bahwa siswa memerlukan banyak persiapan lebih untuk ujian program linier dan ujian mata pelajaran lainnya $(\mathrm{M}=4.21, \mathrm{SD}=0,991)$. Perlunya siswa melakukan persiapan sebelum ujian dengan menguasi materi program linier agar mendapatkan hasil ujian yang memuaskan. Hal ini sesuai dengan (Neuderth et al., 2009) bahwa siswa yang merasakan cemas saat ujian merupakan masalah yang dapat mempengaruhi akademik siswa dan dapat menyebabkan adanya masalah psikologis dan menghambat pengembangan akademis siswa. Dengan demikian siswa perlu meningkatkan pengetahuan dan kemampuan serta minat belajar terhadap matematika pada materi program linier agar siswa siap ketika menghadapi ujian dan untuk meningkatkan prestasi belajar siswa pada materi program linier. Hal ini sejalan dengan (Aarnos \& Perkkilä, 2012) bahwa tanpa ada dorongan semangat dalam diri siswa akan sulit untuk meningkatkan kemampuan matematika. Ketika persiapan siswa yang tidak maksimal akibat kurangnya kinerja siswa dalam belajar matematika, siswa akan merasa kesulitan saat mengerjakan ujian matematika pada materi program linier dan merasa rendah diri hingga membandingkannya dengan orang lain, hal ini juga sesuai dengan pernyataan "Selama ujian materi program linier, siswa membandingkan perkembangan dirinya dengan teman-temannya" $(\mathrm{M}=3.51, \mathrm{SD}=1.192)$. Hal tersebut membuat siswa memiliki pemikiran mengenai batas kemampuan yang dimilikinya dimana mereka berpikir apakah kemampuan mereka termasuk tinggi atau rendah jika dibandingkan dengan orang lain. Sependapat dengan (Kargar et al., 2010) bahwa kecemasan siswa dapat dipengaruhi oleh pemikiran dan sikap yang dimiliki oleh siswa. Siswa yang terlihat sudah memahami materi tersebut terkadang suka merasa kesulitan 
saat mengerjakan ujian dimana hal tersebut terdapat dalam pernyatan "Saya merasa bahwa saya dapat memahami materi program linier di kelas tapi tidak dapat mengerjakannya saat ujian" (M $=3.47, \mathrm{SD}=1.158$ ). Siswa yang kurang pemahamannya dalam materi program linier membuat siswa merasa tidak yakin dimana berkaitan dengan pernyataan "Saya tidak percaya diri saat mengerjakan ujian materi program linier walaupun saya sudah banyak belajar" $(\mathrm{M}=3.40, \mathrm{SD}$ $=1.159)$

\section{Faktor Lingkungan}

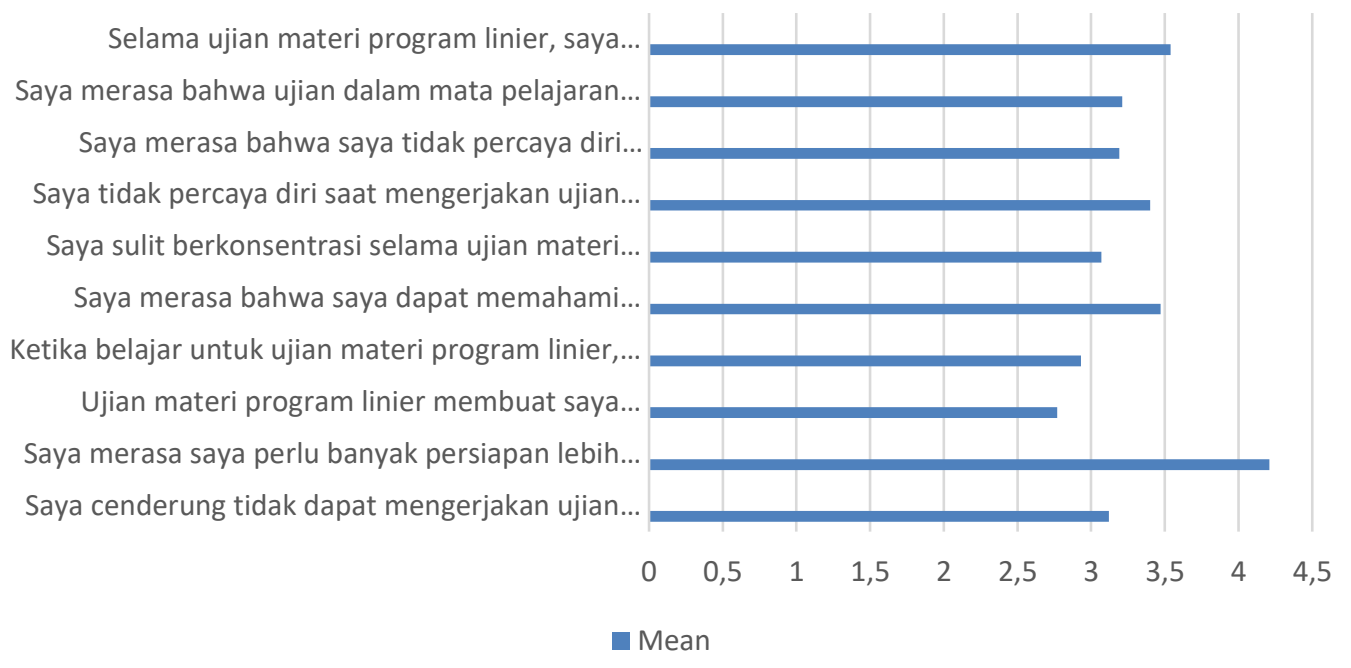

Pernyataan rata-rata kecemasan paling banyak pada siswa yaitu "Saya merasa saya perlu banyak persiapan lebih untuk ujian materi program linier atau mata pelajaran lainnya." dengan nilai $\mathrm{M}=4.21, \mathrm{SD}=0.991$. Sedangkan pernyataan rata-rata kecemasan paling sedikit pada siswa yaitu "Ujian materi program linier membuat saya stress dari pada mata pelajaran lainnya." $(\mathrm{M}=2,77, \mathrm{SD}=1.140)$.

\section{Kecemasan Kategori Lingkungan}

Tabel 4. Kategori: Lingkungan

\begin{tabular}{|c|c|c|c|}
\hline Pernyataan & Mean & SD & Rank \\
\hline $\begin{array}{l}\text { Saya merasa bahwa saya tidak pernah bisa belajar materi } \\
\text { program linier walaupun saya sudah berusaha keras. }\end{array}$ & 2.65 & .977 & 6 \\
\hline $\begin{array}{l}\text { Saya merasa bahwa orang lain memiliki pikiran yang lebih } \\
\text { "matematis" atau "logis" daripada saya. }\end{array}$ & 3.38 & 1.143 & 1 \\
\hline $\begin{array}{l}\text { Orang tua dan teman-teman saya memberitahu saya mengenai } \\
\text { perjuangan dan tekanan mereka terhadap materi program } \\
\text { linier. }\end{array}$ & 1.91 & .994 & 8 \\
\hline $\begin{array}{l}\text { Saya mempercayai orang-orang yang membantu saya dalam } \\
\text { menghadapi situasi materi program linier setiap hari. }\end{array}$ & 3.14 & 1.069 & 3 \\
\hline $\begin{array}{l}\text { Saya merasa dalam materi program linier, jawabannya bisa } \\
\text { benar atau salah dan hanya sedikit dari keduanya. }\end{array}$ & 3.12 & .879 & 4 \\
\hline $\begin{array}{l}\text { Saya memiliki guru materi program linier yang tidak saya } \\
\text { sukai karena satu alasan atau lainnya. }\end{array}$ & 1.87 & 1.082 & 9 \\
\hline $\begin{array}{l}\text { Saya merasa khawatir mengenai kemampuan materi program } \\
\text { linier orang lain dan membandingkannya dengan kemampuan } \\
\text { diri saya. }\end{array}$ & 3.19 & 1.174 & 2 \\
\hline $\begin{array}{l}\text { Saya merasa bahwa meskipun saya berbakat dalam beberapa } \\
\text { hal, tapi tidak ada yang membantu saya dalam materi program } \\
\text { linier. }\end{array}$ & 2.68 & 1.238 & 5 \\
\hline $\begin{array}{l}\text { Saya pernah dihukum dan dipermalukan di kelas materi } \\
\text { program linier karena tidak memahami materi program linier. }\end{array}$ & 1.22 & 660 & 10 \\
\hline
\end{tabular}


Volume 1, No 1, Juni 2021, pp. 34-52

\begin{tabular}{llll}
\hline $\begin{array}{l}\text { Saya merasa seperti saya benar-benar tidak pernah memahami } \\
\text { materi program linier dan saya berpura-pura melewatinya. }\end{array}$ & 2.49 & 1.259 & 7 \\
\hline
\end{tabular}

Tabel 4. Memberikan ringkasan hasil kusioner siswa pada faktor lingkungan. Secara umum, siswa setuju bahwa siswa merasa jika orang lain memiliki kemampuan berpikir lebih matematis dan logis $(\mathrm{M}=3.38, \mathrm{SD}=1,143)$. Hal ini sesuai dengan pendapat (Kargar et al., 2010; Nabilah et al., 2021) bahwa dalam kecemasan siswa dapat dipengaruhi oleh pemikiran dan sikap yang dimiliki oleh siswa. Dalam memahami materi matematika, siswa perlu mengkondisikan sikap dan kemampuan berpikir yang dimilikinya agar dapat menguasai materi matematika pada materi program linier dengan lebih matematis, logis dan kritis. Menurut (Ashcraft, 2002) siswa yang mempunyai tingkat kecemasan yang tinggi akan muncul sikap negatif dan persepsi negatif mengenai kemampuan siswa terhadap matematika. Ketika orang lain memiliki tingkat penalaran yang cukup tinggi, maka siswa tersebut akan dipengaruhi pemikiran negatif terhadap kemampuannya pada materi matematika. Pemikiran negatif yang dimiliki oleh siswa dapat membuat siswa merasa tidak percaya diri atas kemampuan matematika yang masih rendah. Siswa yang mempunyai perasaan tersebut akan muncul perasaan khawatir ketika kemampuannya merasa lebih rendah dari pada orang lain, sesuai pada pernyataan "siswa merasa khawatir mengenai kemampuan orang lain terhadap materi program linier dan membandingkannya dengan kemampuan yang dimilikinya" $(\mathrm{M}=3.19, \mathrm{SD}=1,174)$. Hal ini sejalan dengan (Finlayson, 2014) bahwa rasa cemas juga dapat disebabkaan ketika orang lain yang memiliki pengetahuan dan kemampuan yang lebih terhadap matematika dibandingkan dirinya sendiri. Timbulnya kecemasan yang dialami oleh siswa saat menyelesaikan permasalahan dalam program linier diakibatkan karena kurangnya pemahaman siswa pada materi tesrebut. Kurangnya kemampuan pemahaman siswa membuat mereka membutuhkan orang lain untuk membantu menyelesaikan permasalahan pada materi program linier, hal ini selaras dengan pernyataan "Saya mempercayai orang-orang yang membantu saya dalam menghadapi situasi materi program linier setiap hari" $(\mathrm{M}=3.14, \mathrm{SD}=1.069)$ dimana pernyataan tersebut merupakan sebab dari pernyataan "Saya merasa dalam materi program linier, jawabannya bisa benar atau salah dan hanya sedikit dari keduanya $(\mathrm{M}=3.12, \mathrm{SD}=$ 0.879).

\section{Faktor Lingkungan}

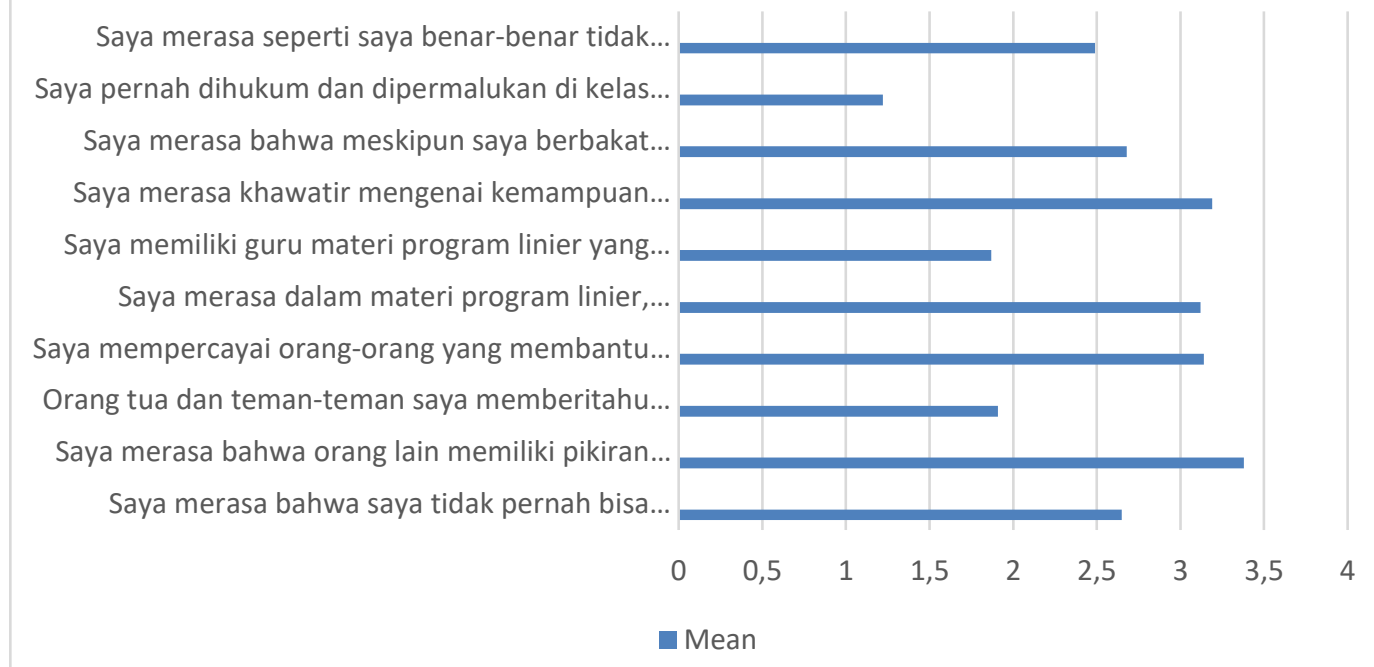

Pernyataan rata-rata kecemasan paling banyak pada siswa yaitu "Saya merasa bahwa orang lain memiliki pikiran yang lebih "matematis" atau "logis" daripada saya." dengan nilai 
$\mathrm{M}=3,38, \mathrm{SD}=1,143$. Sedangkan pernyataan rata-rata kecemasan paling sedikit pada siswa yaitu "Saya pernah dihukum dan dipermalukan di kelas materi program linier karena tidak memahami materi program linier." $(\mathrm{M}=1.22, \mathrm{SD}=0,660)$

\section{Simpulan}

Berdasarkan hasil studi ini dapat dijelaskan bahwa kebayakan siswa merasa cemas saat pembelajaran matematika pada kelas virtual. Kecemasan yang timbul didasarkan atas persepsi negative awal siswa terhadap matematika pada masa pembelajaran periode sebelumnya. Kondisi pandemi dengan pembelajaran matematika secara virtual menambah kecemasan yang terjadi pada siswa. Ketika orang lain memiliki tingkat penalaran yang cukup tinggi, maka siswa tersebut akan dipengaruhi pemikiran negatif terhadap kemampuannya pada materi matematika. Pemikiran negatif yang dimiliki oleh siswa dapat membuat siswa merasa tidak percaya diri atas kemampuan matematika yang masih rendah. Dengan hasil penelitian ini dapat direkomendasikan bahwa pembelajaran matematika secara virtual dapat dilakukan dengan memperhatikan kecemasan sehingga proses pembelajaran matematika dapat berjalan secara efektif.

\section{Konflik Kepentingan}

Penulis menyatakan tidak ada konflik kepentingan

\section{Referensi}

Aarnos, E., \& Perkkilä, P. (2012). Early Signs of Mathematics Anxiety? Procedia - Social and Behavioral Sciences, 46(2003), 1495-1499. https://doi.org/10.1016/j.sbspro.2012.05.328

Ashcraft, M. H. (2002). Math Anxiety: Personal, Educational, and Cognitive Consequences. Current Directions in Psychological Science, 11(5), 181185. https://doi.org/https://doi.org/10.1111/1467-8721.00196

Ashcraft, M. H., \& Faust, M. W. (1994). Mathematics Anxiety And Mental Arithmetic Performance: An Exploratory Investigation. Cognition and Emotion, 8(2), 97125. https://doi.org/10.1080/02699939408408931

Bakhri, S., Sari, A. F., \& Ernawati, A. (2019). Kualitas Pembelajaran Kontekstual Siswa IPS Materi Program Linier yang Memiliki Kecemasan Belajar Matematika. Kreano, Jurnal Matematika Kreatif-Inovatif, 10(2), 186-192. https://doi.org/10.15294/kreano.v10i2.19061

Bayu, A. (2015). Menyelesaikan Permasalahan Program Linear Menggunakan Geogebra. Prosiding Seminar Nasional Teknologi Pendidikan, 1(2), 69.

Bunyamin, B., Umam, K., \& Lismawati, L. (2020). Critical Review of M-Learning in Total Quality Management Classroom Practice in an Indonesian Private University. International Journal of Interactive Mobile Technologies (IJIM), 14(20), 7690. https://doi.org/10.3991/ijim.v14i20.15141

Dabbagh, N. (2007). The online learner: Characteristics and pedagogical implications. Contemporary Issues in Technology and Teacher Education, 7(3), 217226. https://doi.org/10.1007/springerreference 302098 
Devine, A., Fawcett, K., Szucs, D., \& Dowker, A. (2012). Gender differences in mathematics anxiety and the relation to mathematics performance while controlling for test anxiety. Behavioral and Brain Functions, 8, 1-9. https://doi.org/10.1186/1744-9081-8-33

Dhawan, S. (2020). Online Learning: A Panacea in the Time of COVID-19 Crisis. Journal of Educational Technology Systems, 0(0), 1-18. https://doi.org/10.1177/0047239520934018

Finlayson, M. (2014). Addressing Math Anxiety in The Classroom. Improving Schools, 17(1), 99-115. https://doi.org/10.1177/1365480214521457

Georgewill, J. W. (1990). Causes of poor achievement in west african school certificate mathematics examinations in rivers state secondary schools, nigeria. International Journal of Mathematical Education in Science and Technology, 21(3), 379385. https://doi.org/10.1080/0020739900210305

Govindasamy, T. (2001). Successful implementation of e-Learning Pedagogical considerations. Internet and Higher Education, 4(3-4), 287-299. https://doi.org/10.1016/S1096$\underline{7516(01) 00071-9}$

Hasan, N., \& Bao, Y. (2020). Impact of “e-Learning crack-up" perception on psychological distress among college students during COVID-19 pandemic: A mediating role of "fear of academic year loss." Children and Youth Services Review, 118(July), 105355. https://doi.org/10.1016/j.childyouth.2020.105355

Hembree, R. (1990). The Nature, Effects, and Relief of Mathematics Anxiety. Journal for Research in Mathematics Education, 21(1), 3346. https://doi.org/10.5951/jresematheduc.21.1.0033

Ikram, M., Purwanto, \& Parta, I. N. (2021). Analisis Terjadinya Penalaran Reversibel Untuk Kasus Invers: Studi Kasus Pada Subjek Adjie. International Journal of Progressive Mathematics Education, 1(1), 1-15. https://doi.org/10.22236/ijopme.v1i1.6635

Indrawatiningsih, N. (2017). Peningkatan Hasil Belajar Matematika Melalui Model Pembelajaran Scramble Dengan Pemanfaatan Macromedia Flash. JP2M (Jurnal Pendidikan Dan Pembelajaran Matematika), 2(1), 1. https://doi.org/10.29100/jp2m.v2i1.211

Kargar, M., Tarmizi, R. A., \& Bayat, S. (2010). Relationship between Mathematical Thinking, Mathematics Anxiety and Mathematics Attitudes among University Students. Procedia Social and Behavioral Sciences, 8, 537-542. https://doi.org/10.1016/j.sbspro.2010.12.074

Kosiret, A., Indiyah, F. H., \& Wijayanti, D. A. (2021). Peningkatan Kemampuan Pemahaman Konsep Matematis Siswa SMA Islam Al-Azhar 19 Dengan menggunakan Model Pembelajaran Generatif. International Journal of Progressive Mathematics Education, 1(1), 16-26. https://doi.org/10.22236/ijopme.v1i1.6593

Lee, J. (2009). Universals and specifics of math self-concept, math self-efficacy, and math anxiety across 41 PISA 2003 participating countries. Learning and Individual Differences, 19(3), 355-365. https://doi.org/10.1016/j.lindif.2008.10.009 
Moore, J. L., Dickson-Deane, C., \& Galyen, K. (2011). E-Learning, online learning, and distance learning environments: Are they the same? Internet and Higher Education, 14(2), 129-135. https://doi.org/10.1016/j.iheduc.2010.10.001

Nabilah, E., Azhar, E., Purwanto, S. E., \& Nabilah, E. (2021). Kecemasan Siswa Dalam Menyelesaikan Masalah Modelling Matematika Pada Praktek Kelas Virtual. Internatioinal Journal of Progressive Mathematics Education, 1(1), 4160. https://doi.org/10.22236/ijopme.v1i1.6595

Nakhanu, S. B., \& Musasia, A. Ma. (2015). Problem based learning technique and its effect on acquisition of linear programming skills by secondary school students in Kenya. Journal of Education and Practice, 6(20), 68-75.

Neuderth, S., Jabs, B., \& Schmidtke, A. (2009). Strategies for reducing test anxiety and optimizing exam preparation in German university students: A prevention-oriented pilot project of the University of Würzburg. Journal of Neural Transmission, 116(6), 785790. https://doi.org/10.1007/s00702-008-0123-7

Peker, M. (2009). Pre-service teachers' teaching anxiety about mathematics and their learning styles. Eurasia Journal of Mathematics, Science and Technology Education, 5(4), 335345. https://doi.org/10.12973/ejmste/75284

Radišić, J., Videnović, M., \& Baucal, A. (2015). Math anxiety-contributing school and individual level factors. European Journal of Psychology of Education, 30(1). https://doi.org/10.1007/s10212-014-0224-7

Richardson, F. C., \& Suinn, R. M. (1972). The Mathematics Anxiety Rating Scale: Psychometric data. Journal of Counseling Psychology, 19(6), 551554. https://doi.org/10.1037/h0033456

Saputra, P. R. (2014). Kecemasan Matematika dan Cara Menguranginya ( Mathematic Anxiety and How To Reduce It ). Journal of Chemical Information and Modeling, 1(1), 16891699. https://doi.org/http://dx.doi.org/10.33373/pythagoras.v3i2.590

Scarpello, G. (2007). Helping Student Get Past Math Anxiety. Connecting Education and Careers, 34-35. https://doi.org/10.1126/science.237.4822.1556

Şengül, S., \& Dereli, M. (2010). Does instruction of "Integers" subject with cartoons effect students' mathematics anxiety? Procedia - Social and Behavioral Sciences, 2(2), 21762180. https://doi.org/10.1016/j.sbspro.2010.03.302

Sorvo, R., Koponen, T., Viholainen, H., Aro, T., Räikkönen, E., Peura, P., Dowker, A., \& Aro, M. (2017). Math anxiety and its relationship with basic arithmetic skills among primary school children. British Journal of Educational Psychology, 87(3), 309327. https://doi.org/10.1111/bjep.12151

Sugiatno, Priyanto, D., \& Riyanti, S. (2017). Tingkat Dan Faktor Kecemasan Matematika Pada Siswa Sekolah Menengah Pertama. Jurnal Pendidikan Dan Pembelajaran Untan, 6(10), 217220.

Sugiyono, P. D. (2018). Metode Penelitian Kuantitatif. Alfabeta. 
Umam, K., Nusantara, T., Parta, I. N., Hidayanto, E., \& Mulyono, H. (2019). An application of flipped classroom in mathematics teacher education programme. International Journal of Interactive Mobile Technologies, 13(3). https://doi.org/10.3991/ijim.v13i03.10207

Vitasari, P., Herawan, T., Wahab, M. N. A., Othman, A., \& Sinnadurai, S. K. (2010). Exploring Mathematics Anxiety among Engineering students. Procedia - Social and Behavioral Sciences, 8, 482-489. https://doi.org/10.1016/j.sbspro.2010.12.066

Wahid, S. N. S., Yusof, Y., \& Razak, M. R. (2014). Math Anxiety among Students in Higher Education Level. Procedia - Social and Behavioral Sciences, 123, 232237. https://doi.org/10.1016/j.sbspro.2014.01.1419 